\title{
Dopamine synthesis and dopamine receptor expression are disturbed in recurrent miscarriages
}

\author{
Michael J Gratz' ${ }^{1}$, Stavroula Stavrou ${ }^{1}$, Christina Kuhn ${ }^{1}$, Simone Hofmann ${ }^{1}$, Kerstin Hermelink ${ }^{1}$, \\ Helene Heidegger ${ }^{1}$, Stefan Hutter ${ }^{1}$, Doris Mayr ${ }^{2}$, Sven Mahner', Udo Jeschke ${ }^{1}$ and Aurelia Vattai ${ }^{1}$ \\ ${ }^{1}$ Department of Obstetrics and Gynecology, University Hospital, LMU Munich, Munich, Germany \\ ${ }^{2}$ Department of Pathology, University Hospital, LMU Munich, Munich, Germany
}

Correspondence should be addressed to U Jeschke: udo.jeschke@med.uni-muenchen.de

\begin{abstract}
Objectives: L-dopa decarboxylase (DDC) is responsible for the synthesis of dopamine. Dopamine, which binds to the $D_{2}$-dopamine receptor (D2R), plays an important role in the maintenance of pregnancy. Aim of our study was the analysis of DDC and D2R expression in placentas of spontaneous miscarriages (SMs) and recurrent miscarriages (RMs) in comparison to healthy controls.

Methods: Patients with SM $(n=15)$ and RM $(n=15)$ were compared with patients from healthy pregnancies $(n=15)$ (pregnancy weeks 7-13 each). Placental tissue has been collected from SMs and RMs from the first trimester (Department of Gynaecology and Obstetrics, LMU Munich) and from abruptions (private practice, Munich). Placental cell lines, BeWo- and JEG-3 cells, were stimulated with the trace amines $T_{0} A M$ and $T_{1} A M$ in vitro.

Results: Levels of DDC and D2R in trophoblasts and the decidua were lower in RMs in comparison to healthy controls. Stimulation of BeWo cells with $\mathrm{T}_{1} \mathrm{AM}$ significantly reduced DDC mRNA and protein levels. Via double-immunofluorescence, a DDC-positive cell type beneath decidual stromal cells and foetal EVT in the decidua could be detected. Conclusions: Downregulation of DDC and D2R in trophoblasts of RMs reflects a reduced signal cascade of catecholamines on the foetal side.
\end{abstract}

\author{
Key Words \\ - L-dopa-decarboxylase \\ - dopamine D2L receptor \\ - thyronamine \\ - 3-iodothyronamine \\ - miscarriages
}

\section{Introduction}

The $\mathrm{D}_{2}$-dopamine receptor (D2R) is expressed by the human placenta, and its expression increases with the gestational week, and it reaches a maximum at term (1). Dopamine plays a significant role in human placental endocrine function, and it has the ability to inhibit human placental lactogen (hPL) and human chorionic gonadotrophin production (2). Changes in placental D2R expression have been observed in pregnant patients with preeclampsia and hydatidiform moles, which consequently leads to modulations in signal transduction processes (1). D2R is a target receptor for various antipsychotic drugs, and it can interact with the trace amine-associated receptor 1 (TAAR1), forming a functional heteromer $(3,4)$.

The enzyme L-dopa-decarboxylase (aromatic amino acid decarboxylase, DDC), which is expressed by the placenta, is responsible for the conversion of L-dopa into dopamine $(5,6)$. Additionally, DDC is involved in the synthesis of serotonin, tryptamine, phenylethylamine and histamine (12). DDC can be subjected to multiple regulatory mechanisms at various levels (7).

Degradation of thyroid hormones results in the formation of trace amines (TAs), also referred to as
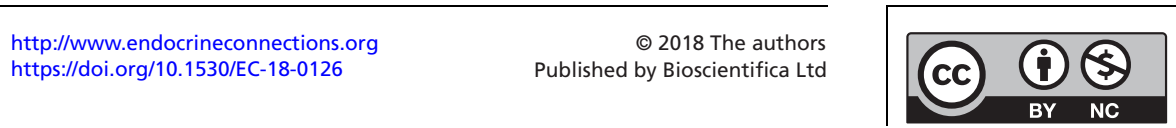

This work is licensed under a Creative Commons Attribution-NonCommercial 4.0 International License. 
endogenous amines or thyronamines (3). TAs (3- $\mathrm{T}_{1} \mathrm{AM}$, $\mathrm{T}_{0} \mathrm{AM}$ ) are converted from L-thyroxin also through a decarboxylation process (8). As TAs and catecholamines are both derived from decarboxylation of the original amino acid tyrosine, a connection exists between their synthesis and their structure. TAs affect dopamine signalling through TAAR1 and D2R heteromers (3). In a recent study, we found an increase of TAAR1 levels in placental tissue of patients with spontaneous miscarriages (SMs) and recurrent miscarriages (RMs). We linked those findings with a possible increase in thyroid hormone degradation through decarboxylation in placental tissue (27).

Thyroid hormones play an important role during trophoblast differentiation and the neurofoetal development (9). They bind to the thyroid hormone receptor (THR), which belongs to the nuclear receptor superfamily. Nuclear receptors play a role in various physiological processes, and they act via transcriptional cis-regulation of target genes (10). The choline acetyltransferase and DDC are target genes for thyroid hormones, and gene expression is regulated through those enzymes (11).

Thyroid disorders such as hypothyroidism and hyperthyroidism are associated with miscarriages and stillbirths (12). Untreated hypothyroidism can result in a twofold increase of miscarriages and stillbirth rates; hence, the maintenance of an euthyroid state is crucial for a healthy pregnancy (13). Downregulation of THR expression in miscarriages can possibly be a compensatory reaction towards an increased concentration of thyroid hormone metabolites. Placental expression of the isoforms THR $\alpha 1, T H R \beta 1$ and THR $\alpha 2$ increases with gestational age (14). In a previous study, we could demonstrate that mRNA and protein expression of THR $\alpha 1$, THR $\alpha 2$, THR $\beta 1$ and THR $\beta 2$ is downregulated in SMs and RMs (15). Classical thyroid hormones act epigenetically, while decarboxylated thyroid hormones act in the opposite direction through rapid actions like rapid lowering of body temperature and heart rate (16).

Aim of our study was to analyse the expression of DDC and D2R in healthy pregnancies and SMs as well as RMs, and to further identify the mechanisms that are responsible for the regulation of thyroid hormones during miscarriages. Additionally, the influence of thyroid hormone metabolites on the expression of DDC in trophoblast model cells was assessed in order to identify ligands that may partly be responsible for the induction of miscarriages.

\section{Materials and methods}

\section{Tissue samples}

Samples were retrieved from SMs (15 cases) and RMs (15 cases), which were obtained from the archives of the Gynaecology and Obstetrics Department of the Ludwig Maximilians University of Munich, Germany, and which were collected between 2011 and 2012. Samples from elective terminations of pregnancy (ETPs, 15 cases) were collected in a private practice in Munich in the same time period. All women included in the study had no medical or family history. Hypothyroidism as well as hyperthyroidism were excluded in all women. History taking was systematic, aiming to exclude - apart from common disorders - the possible implication of clotting disorders and autoimmune diseases, already known as aggravating factors for increased risk for miscarriages. In all samples, analysis of chromosomal abnormalities was performed (15). Tissue samples were obtained by dilatation and curettage without any prior pharmaceutical induction. In cases of miscarriages, curettage was performed within $24 \mathrm{~h}$ after diagnosis. The average gestational age for SM was $10.1 \pm 1.5$ weeks, for RM $10 \pm 1.5$ weeks and for ETP $10.6 \pm 2.1$ weeks. The mean maternal age for SM was 37.3 \pm 4.1 years, for RM 37.6 \pm 6.2 years and for ETP $32 \pm 8.2$ years. Further demographic and clinical data are shown in Table 1.

\section{Ethical approval and informed consent}

All procedures involving human participants were in accordance with the Ethical Standards of the Institutional

Table 1 Maternal data overview.

\begin{tabular}{|c|c|}
\hline Characteristic (unit) & $\begin{array}{l}\text { Elective termination } \\
\text { of pregnancies }(n=15)\end{array}$ \\
\hline Maternal age (years) & $32.4 \pm 8.2(20-45)$ \\
\hline Gestational age (weeks of pregnancy) & $9.6 \pm 2.1(7-13)$ \\
\hline Gravidity & $3.9 \pm 2.1(1-7)$ \\
\hline Parity & $2.0 \pm 1.3(0-4)$ \\
\hline
\end{tabular}

\begin{tabular}{c}
$\begin{array}{c}\text { Spontaneous } \\
\text { miscarriages }(n=15)\end{array}$ \\
\hline $37.3 \pm 4.1(31-44)$ \\
$9.1 \pm 1.5(7-12)$ \\
$1.3 \pm 0.5(1-2)$ \\
$0.2 \pm 0.4(0-1)$ \\
\hline
\end{tabular}

\begin{tabular}{|c|c|}
\hline $\begin{array}{c}\text { Recurrent } \\
\text { miscarriages }(n=15)\end{array}$ & $\begin{array}{c}\boldsymbol{P} \text { value } \\
\text { (Kruskal-Wallis test) }\end{array}$ \\
\hline $37.6 \pm 6.2(22-45)$ & 0.105 \\
\hline $9.0 \pm 1.5(7-12)$ & 0.786 \\
\hline $3.6 \pm 1.2(2-5)$ & 0.002 \\
\hline $1.3 \pm 1.1(0-3)$ & 0.009 \\
\hline
\end{tabular}

Values are given as mean \pm S.D.; the range is given in parentheses.

$$
\begin{aligned}
& \text { http://www.endocrineconnections.org } \\
& \begin{array}{l}
\text { https://doi.org/10.1530/EC-18-0126 } 2018 \text { The authors } \\
\text { Published by Bioscientifica Ltd }
\end{array}
\end{aligned}
$$


and/or National Research Committee and with the Helsinki Declaration of 1964 and its later amendments or comparable ethical standards. The study was approved by the Local Ethics Committee of the Ludwig Maximilian University of Munich (reference number of approval: 33706). Written informed consent has been obtained from the patients after full explanation of the purpose and nature of all procedures used.

\section{Immunohistochemistry}

Immunohistochemistry was performed as described in our recent study by Stavrou et al. (17). After tissue retrieval, tissue samples were fixed in 3.7\% formalin and embedded in paraffin. Formalin-fixed paraffinembedded sections $(3 \mu \mathrm{m})$ were deparaffinised in Roticlear (Carl Roth, Karlsruhe, Germany), rehydrated and blocked with $6 \% \mathrm{H}_{2} \mathrm{O}_{2} /$ methanol (for DDC) and $3 \%$ $\mathrm{H}_{2} \mathrm{O}_{2} /$ methanol (for D2R) for endogenous peroxidase activity for $20 \mathrm{~min}$. Rehydration of the slides was performed using an alcohol gradient up to distilled water. The slides were then placed in a pressure cooker containing sodium citrate $(\mathrm{pH}=6.0)$. To prevent any nonspecific binding of the primary antibodies, a blocking solution was used (Polymer Kit; Zytomed Systems, Berlin, Germany). Tissue sections were then incubated with the primary antibodies for $16 \mathrm{~h}$ at $4^{\circ} \mathrm{C}$ as listed in Table 2. Reactivity was detected by using the ZytoChem Plus HRP Polymer System (mouse/rabbit) (Zytomed, catalogue-ID: POLHRP-100; Source BioScience, Nottingham, UK) in accordance to the manufacturer's protocol, and staining and counterstaining was carried out with diaminobecidine (DAB), respectively, Hemalaun. Appropriate positive controls (appendix for $\mathrm{D} 2 \mathrm{R}$, colon for DDC) and negative controls (negative control serum added on the third trimester placenta) (Negative Control for Super Sensitive Rabbit Antibodies, Rabbit IgG; Biogenics, Fremont, CA, USA) were included in each experiment (Supplementary Fig. 1, see section on supplementary data given at the end of this article). Per slide, ten fields were examined with the semiquantitative immunoreactive score (IRS) (18) by two independent observers using a Leitz Diaplan microscope
(Leitz, Wetzlar, Germany). The IRS is calculated by multiplying the intensity of cell staining ( 0 : none; 1 : weak; 2: moderate; 3 : strong) with the percentage of positively stained cells ( 0 : no staining; $1:<10 \%$ of the cells; 2: 11-50\%; 3: 51-80\%; 4: >81\%).

\section{Cell lines and cell stimulation}

Cell line experiments were performed as described by Stavrou et al. (17). The choriocarcinoma cell lines BeWo (ECACC, Salisbury, UK) and JEG-3 (ATCC) were used for the study, which are useful models of human trophoblasts. The cells were cultured in DMEM (3.7 g/L NaHCO $3,4.5 \mathrm{~g} / \mathrm{L}$ D-glucose, $1.028 \mathrm{~g} / \mathrm{L}$ stable glutamine and Na-Pyruvate; Biochrom, Berlin, Germany). Ten percent heat-inactivated fetal calf serum (FCS) was supplemented to the medium and the solution was incubated at an atmospheric $\mathrm{CO}_{2}$ concentration of $5 \%$ and at $37^{\circ} \mathrm{C}$.

BeWo and JEG-3 cells were separately grown on sterile 12-multiwell slides at a density of 500,000 cells/ mL DMEM with $10 \%$ foetal cow serum. After $4 \mathrm{~h}$, medium was changed to pure DMEM. The cells were stimulated with $0.01 \mathrm{nM}$ or $0.1 \mathrm{nM}$ thyronamine $\left(\mathrm{T}_{0} \mathrm{AM}\right.$ ) (SigmaAldrich, catalogue-ID: 80345), 3-iodothyronamine ( $\left.\mathrm{T}_{1} \mathrm{AM}\right)$ (Cayman Chemical) and RO5203548 (Glixx Laboratories, Hopkinton, MA, USA) for $2 \mathrm{~h}$ (PCR samples) and $48 \mathrm{~h}$ (immunocytochemistry and Western blot samples), respectively. Control cells were incubated sans stimulants.

\section{Immunocytochemistry}

After an incubation of $48 \mathrm{~h}$, the Quadriperm slides were fixated in an ethanol/methanol solution for $15 \mathrm{~min}$. Between each of the experimental steps, the slides were washed in PBS (Biochrom). Next, the primary antibodies anti-DDC (polyclonal Rabbit IgG; LSBio, Seattle, WA, USA) and anti-DRD2 (polyclonal Rabbit IgG; LSBio) were applied for $16 \mathrm{~h}$ at $4^{\circ} \mathrm{C}$. Incubation with the secondary antibody Reagent II from the ZytoChem Plus HRP Polymer System (mouse/rabbit) (Zytomed: Nr. POLHRP-100) for $20 \mathrm{~min}$ at $4^{\circ} \mathrm{C}$ and afterwards with Reagent III for $30 \mathrm{~min}$ at room temperature followed. Next, the slides were incubated with the $\mathrm{ABC}$ complex for $30 \mathrm{~min}$. Staining of the slides

Table 2 Features of the antibodies used for staining.

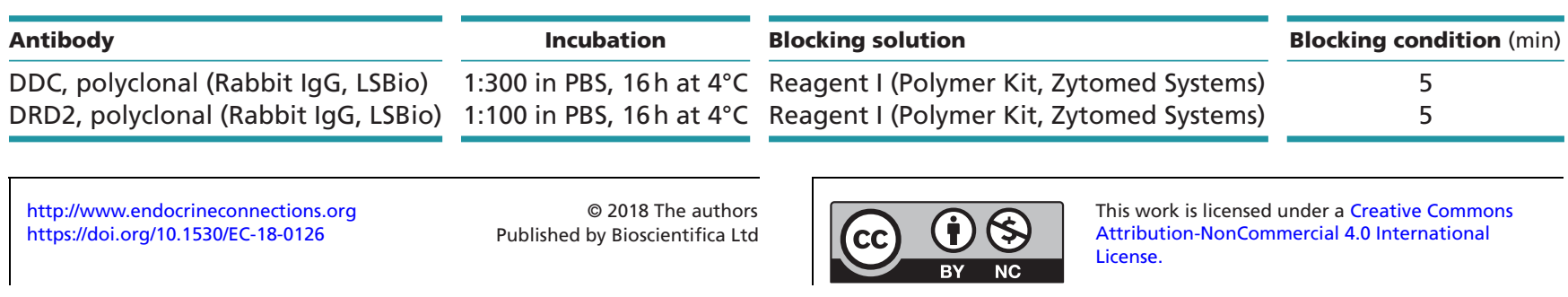


was carried out with 3-amino-9-ethylcarbazole plus (AEC plus; Dako) for $8 \mathrm{~min}$, followed by counterstaining with Hemalaun for $30 \mathrm{~s}$, washing in tap water and coverslipping of the slides.

Examination and evaluation of the slides were carried out with a Leitz Diaplan light microscope (Leitz) and a digital camera system (JVC, Yokohoma, Japan). Two independent observers examined the slides.

For each slide, six visual fields were examined at $10 \times$ overall magnification. For each field, all cells were counted and assigned to three groups (negative, low and medium/ strong staining).

\section{TaqMan-real-time PCR}

TaqMan PCR was performed as described by Pestka et al. (19). RNA of stimulated and control JEG-3 and BeWo cells was isolated using the NucleoSpinRNAII (MachereyNagel, Düren, Germany). Quantification and evaluation of RNA samples was performed with the NanoPhotometer (Implen, Munich, Germany).

Reverse transcription was carried out using the High-Capacity cDNA reverse transcription kit (Applied Biosystems) with a temperature protocol of $25^{\circ} \mathrm{C}$ for $10 \mathrm{~min}, 37^{\circ} \mathrm{C}$ for $2 \mathrm{~h}, 85^{\circ} \mathrm{C}$ for $5 \mathrm{~s}$ and final cooling at $4^{\circ} \mathrm{C}$.

PCR was performed in 96-well reaction plates holding a volume of $20 \mu \mathrm{L}$. Each well contained $1 \mu \mathrm{L}$ TaqMan Gene Expression Assay 20× (Applied Biosystems), $10 \mu \mathrm{L}$ TaqMan Universal PCR Master Mix 2× (Applied Biosystems), $8 \mu \mathrm{L}$ $\mathrm{H}_{2} \mathrm{O}$ (DEPC-treated DI water, Sigma) and $1 \mu \mathrm{L}$ sample. For the PCR assay, the ABI PRISM 7500 Fast (Applied Biosystems) was used with thermal cycling conditions of $20 \mathrm{~s}$ at $95^{\circ} \mathrm{C}$ followed by 40 cycles of amplification with $3 \mathrm{~s}$ at $95^{\circ} \mathrm{C}$ and $30 \mathrm{~s}$ at $60^{\circ} \mathrm{C}$. To quantify the expression, the $2^{-\Delta \Delta C T}$ method was used applying $\beta$-actin as the housekeeping gene. Each experiment was validated three times.

\section{Western blot}

Stimulated cell samples were lysed for $30 \mathrm{~min}$ with $200 \mu \mathrm{L}$ buffer solution consisting of a 1:100 dilution of protease inhibitor (Sigma-Aldrich) in RIPA buffer (Radioimmunoprecipitation assay buffer, SigmaAldrich). The lysate was centrifuged, and a Bradford protein assay of the supernatant was performed. The proteins were separated according to their molecular weight using SDS-PAGE and transferred onto a PVDF membrane (Merck Millipore). Non-specific binding was blocked through a $1 \mathrm{~h}$ incubation of the membrane

$$
\text { http://www.endocrineconnections.org }
$$

with Marvel-TBST for DDC staining and with $1 \times$ Casein Solution (Vector Laboratories, Burlingame, CA, USA) for $\beta$-Actin staining. The primary antibodies anti-DDC (polyclonal Rabbit IgG; LSBio) and Anti- $\beta$-Actin (Clone AC-15, Mouse IgG, Sigma), diluted in a 1:1000 in Marvel-TBST (TBS + Tween and milk powder) and 1:1000 Casein solution, respectively, were applied for $16 \mathrm{~h}$ at $4^{\circ} \mathrm{C}$ for $\beta$-actin and $1 \mathrm{~h}$ at room temperature for DDC. After rinsing with TBST, the membrane was incubated with biotinylated anti-rabbit IgG antibody and ABCAmP reagent (both Vectastain ABC-AmP Kit for rabbit IgG, Vector Laboratories) following the manufacturer's protocol. Staining was performed using BCIP/NBT chromogenic substrate (Vectastain ABC-AmP Kit, Vector Laboratories). Detection was performed with Bio-Rad Universal Hood II (Bio-Rad Laboratories) and the findings were quantified using Bio-Rad Quantity One software (Bio-Rad Laboratories).

\section{Double-immunofluorescence}

To determine the cells that express D2R and DDC in the decidua, double-immunofluorescence analysis with markers for extravillous trophoblast (EVT) and decidual stroma cells was performed. Human leukocyte antigen G (HLAG), which is a marker for EVT, and prolactin, a marker for decidual stroma cells, were applied. Placental tissue of both ETP and RM groups were stained.

Double-immunofluorescence staining was carried out on placental slides of both ETP and RM groups. After retrieval, the tissue samples were fixed in $3.7 \%$ formalin and embedded in paraffin. Formalin-fixed paraffin-embedded sections $(3 \mu \mathrm{m})$ were deparaffinised in Roticlear (Carl Roth), rehydrated and then blocked with $3 \% \mathrm{H}_{2} \mathrm{O}_{2} /$ methanol for endogenous peroxidase activity for $20 \mathrm{~min}$. Rehydration of the slides was accomplished using an alcohol gradient up to distilled water. The slides were then put in a pressure cooker containing sodium citrate $(\mathrm{pH}=6.0)$. Between each experimental step, the slides were washed in PBS (Biochrom) at room temperature and without light exposure. In order to block any non-specific binding of the primary antibodies, the sections were incubated with UltraVision Protein Block (Thermo Scientific, catalogue-ID.: TA060PBQ) for $15 \mathrm{~min}$ at room temperature. Then, the samples were incubated with 1:100 Anti-DRD2 (polyclonal rabbit antibody; LSBio, catalogue-ID: LS-A1403), 1:300 anti-DDC (polyclonal rabbit antibody; LSBio, catalogue-ID: LS-B10123) and 1:50 Anti-HLAG (monoclonal mouse IgG1, clone:

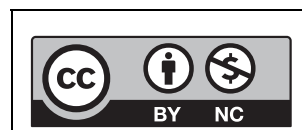
This work is licensed under a Creative Commons
Attribution-NonCommercial 4.0 International License. 
MEM-6/9; Biocompare, South San Francisco, CA, USA, catalogue-ID: MCA2043) antibodies diluted in Antibody Diluent (Dako, catalogue-ID: S3022) for $16 \mathrm{~h}$ at $4^{\circ} \mathrm{C}$. Slides were then exposed to the secondary antibodies, Cy2-labelled goat-anti-mouse IgG (Dianova, Hamburg, Germany), diluted 1:100 in Dako Antibody Diluent and Cy3-labelled goat-anti-rabbit IgG (Dianova) diluted 1:500 in Dako Antibody Diluent. Finally, the sections were embedded in Vectashield Antifade Mounting Medium with 4,6-diamino-2-phenylindole (Vector Laboratories, catalogue-ID: H-1200) and inspected with a fluorescent Axioskop photomicroscope (Zeiss). Images were acquired with a digital Axiocam camera system (Zeiss).

\section{Statistics}

Data collection and processing as well as analysis of statistical data were performed with IBM SPSS Statistics for Windows, version 22.0 (IBM Corp, Armonk, NY). P values smaller than 0.05 were considered statistically significant. Non-parametric Mann-Whitney $U$ test was performed for comparison of means. Wilcoxon signed-rank test was performed for the statistical analysis of cell culture tests. As the causes for either SMs or RMs are different, those groups were not compared with each other.

\section{Results}

\section{DDC protein expression in the placenta}

DDC protein expression in villous trophoblasts of RMs was significantly reduced in comparison to DDC protein expression in villous trophoblasts of normal pregnancies $(P=0.049)$ (Fig. 1; Table 3). In decidual cell populations, DDC protein expression was also significantly downregulated $(P=0.018)$ in RMs (Fig. 1; Table 3). Significant differences of DDC expression between SMs $(P=0.669)$ and healthy controls were found neither in first trimester placentas nor in the decidua $(P=0.252)$ (Fig. 1; Table 3).

\section{D2R protein expression in the placenta}

In syncytiotrophoblasts and villous cytotrophoblasts of RMs, a significant downregulation of D2R staining could be shown in comparison to healthy controls $(P=0.007)$ (Fig. 2; Table 4). In the decidua and glands, no significant difference in D2R protein expression could be detected

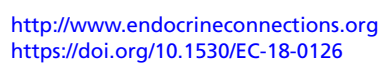

(decidua: $P=0.349$; glands: $P=0.710$ ). In $S M s, D 2 R$ protein expression did not differ from uncomplicated pregnancies (syncytiotrophoblasts: $P=0.469$; decidua: $P=0.756$; glands: $P=0.386)$.

DDC mRNA expression in BeWo trophoblast model cells after stimulation with $\mathrm{T}_{0} \mathrm{AM}$ and $\mathrm{T}_{1} \mathrm{AM}$

Incubation of BeWo cells with $0.1 \mathrm{nM} \mathrm{T}_{0} \mathrm{AM}$ induced a significant downregulation of DDC mRNA expression $(P=0.020)$ (Fig. 3A; Table 5). At a lower concentration $(0.01 \mathrm{nM})$, a downregulation of DDC mRNA could also be shown; however, the difference was not significant $(P=0.394)$ (Fig. 3A; Table 5). The stimulant $\mathrm{T}_{1} \mathrm{AM}$ induced a significant downregulation of DDC mRNA expression in BeWo cells at both concentrations $(P=0.002$ for $0.01 \mathrm{nM}$ and $P=0.025$ for $0.1 \mathrm{nM}$ (Fig. 3A). In JEG-3 cells, $0.01 \mathrm{nM} \mathrm{T}_{1} \mathrm{AM}$ induced a significant $(P=0.005)$ downregulation of DDC mRNA expression (Fig. 3C; Table 5). At a concentration of $0.1 \mathrm{nM}, \mathrm{T}_{1} \mathrm{AM}$ had no effect on the expression of DDC in JEG-3 cells $(P=0.065)$ (Fig. 3C; Table 5).

DDC protein expression in BeWo trophoblast model cells after stimulation with $\mathrm{T}_{0} \mathrm{AM}$ and $\mathrm{T}_{1} \mathrm{AM}$

\section{Immunocytochemistry}

The influence of $\mathrm{T}_{0} \mathrm{AM}$ and $\mathrm{T}_{1} \mathrm{AM}$ on DDC expression in BeWo and JEG-3 cells has also been studied on protein level. Obtained by immunocytochemistry, a significant $(P=0.025)$ downregulation of DDC expression in BeWo cells induced by $0.01 \mathrm{nM} \mathrm{T} \mathrm{AM}_{0}$ could be detected (Fig. 4; Table 6). At a concentration of $0.1 \mathrm{nM}, \mathrm{T}_{1} \mathrm{AM}$ did not lead to a significant difference in DDC protein expression in comparison to unstimulated BeWo cells $(P=0.058)$ (Fig. 4; Table 6). A similar trend could be observed for the endogene ligand $\mathrm{T}_{1} \mathrm{AM}$, which induced a significant downregulation of DDC protein expression in BeWo cells for $0.01 \mathrm{nM}(P<0.001)$ and $0.1 \mathrm{nM}(P=0.002)$ (Fig. 4; Table 6).

\section{Western blot}

The same trend as observed via immunocytochemistry could be detected for Western blotting where $0.01 \mathrm{nM}$ $(P=0.048)$ and $0.1 \mathrm{nM}(P=0.007)$ of $\mathrm{T}_{0} \mathrm{AM}$ induced a significant downregulation of DDC protein expression in BeWo trophoblast model cells (Fig. 5A and C; Table 7). For $\mathrm{T}_{1} \mathrm{AM}$, only the lower concentration level $(0.01 \mathrm{nM})$ induced a significant downregulation of DDC protein

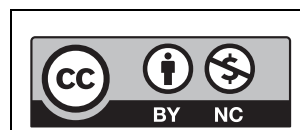

This work is licensed under a Creative Commons Attribution-NonCommercial 4.0 International License. 

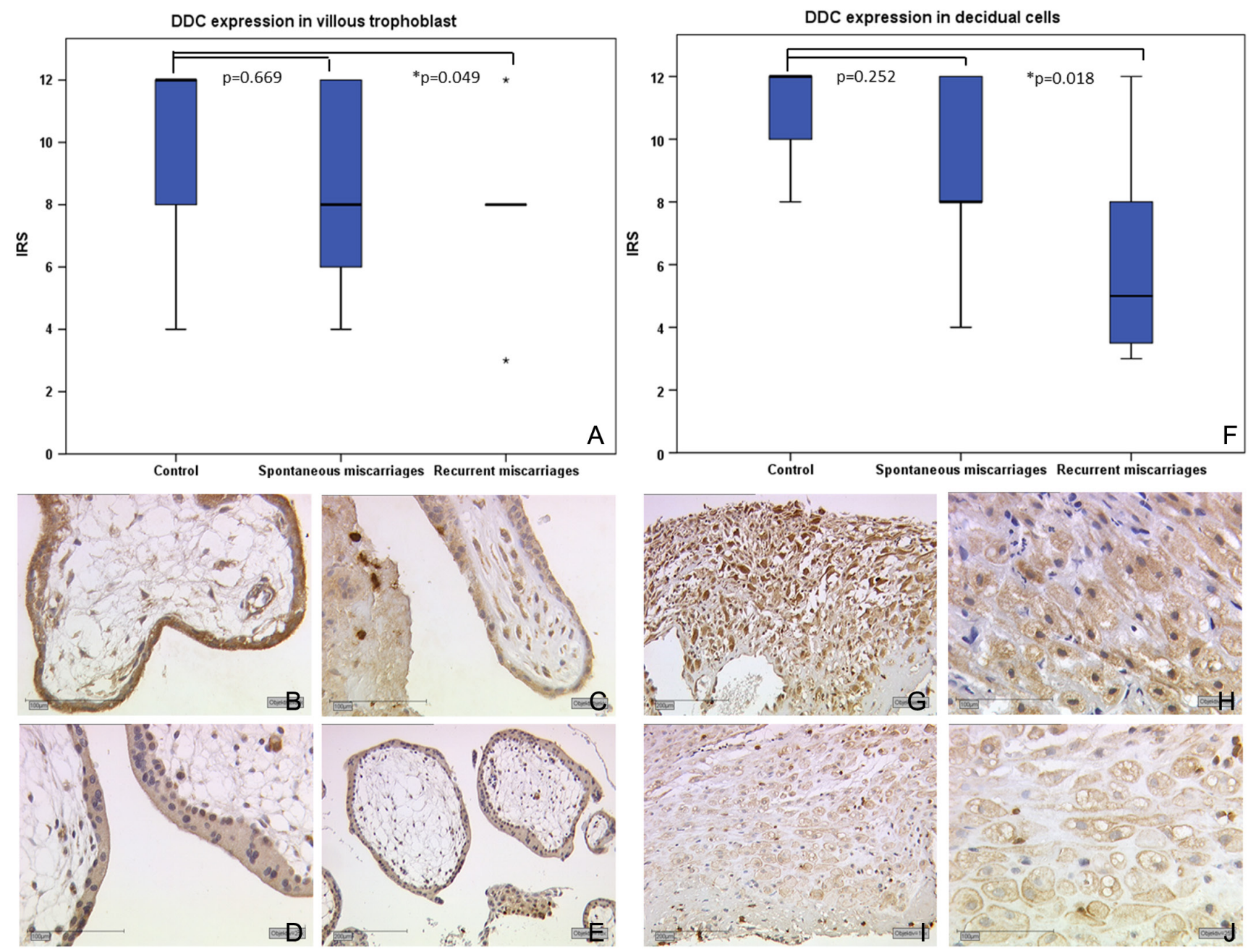

\section{Figure 1}

DDC protein expression in villous trophoblasts and decidual cells. (A) Boxplot of DDC protein expression in villous trophoblasts, (B) stronger DDC staining in villous trophoblasts of control tissue, $\times 25$ magnification, (C) lower DDC staining in villous trophoblasts of SMs, $\times 25$, (D) lower DDC staining of RMs, villous trophoblasts, $\times 25$, (E) lower DDC staining of RMs, villous trophoblasts, $\times 10$, (F) boxplot of DDC protein expression in decidual cells, (G) control decidua, $\times 10,(H)$ control decidua, $\times 25$, (I) RM decidua, $\times 10,(J)$ RM decidua, $\times 25$. DDC, L-dopa decarboxylase; RM, recurrent miscarriage; SM, spontaneous miscarriage.

expression after $48 \mathrm{~h}(P=0.007)$ in BeWo cells (Fig. 5B and C; Table 7).

In JEG-3 cells, a different influence of $\mathrm{T}_{0} \mathrm{AM}$ and $\mathrm{T}_{1} \mathrm{AM}$ on DDC expression could be observed in comparison to BeWo cells. The stimulant $\mathrm{T}_{0} \mathrm{AM}$ led to a significant upregulation of DDC protein expression after an incubation time of $48 \mathrm{~h}$ and at a concentration of $0.1 \mathrm{nM}(P=0.048)$ (Fig. 5D and F; Table 7). The endogene ligand $\mathrm{T}_{1} \mathrm{AM}$ also induced a significantly increased expression of DDC in JEG-3 cells at a concentration of $0.1 \mathrm{nM}(P=0.038)$ (Fig. 5E and F; Table 7). At a lower concentration, both stimulants had no significant influence on DDC expression in JEG-3 cells (Fig. 5D and E; Table 7).

$$
\begin{aligned}
& \text { http://www.endocrineconnections.org } \\
& \text { https://doi.org/10.1530/EC-18-0126 }
\end{aligned}
$$

\section{Coexpression of DDC and D2R in EVTs double-immunofluorescence}

In ETP decidual tissue HLAG-positive cells are stained in green (Fig. 6B), and HLAG-negative cells both expressing D2R are stained in red (Fig. 6A). Triple filter excitation shows the non-exclusive double staining of D2R and HLAG in yellow. In RM decidua, less doubleimmunofluorescence staining can be seen (Fig. 6F), showing that in placentas of RMs, the ETP expresses less $\mathrm{D} 2 \mathrm{R}$ than in healthy pregnancies.

DDC expression in ETP (Fig. 6G) and RM placentas (Fig. 6K), which is stained in red, occurred mostly in HLAG-negative cells. EVT, stained in green, (Fig. $6 \mathrm{H}$ and L)

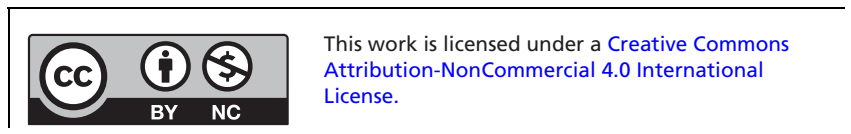


Table 3 Raw numbers to Fig. 1.

\begin{tabular}{|c|c|c|c|}
\hline & IRS mean & IRS 25th percentile & IRS 75th percentile \\
\hline \multicolumn{4}{|c|}{ DDC expression in villous trophoblast } \\
\hline ETP & 12 & 8 & 12 \\
\hline SM & 8 & 6 & 12 \\
\hline RM & 8 & 8 & 8 \\
\hline \multicolumn{4}{|c|}{ DDC expression in decidual cells } \\
\hline ETP & 12 & 10 & 12 \\
\hline SM & 8 & 8 & 12 \\
\hline RM & 5 & 4 & 8 \\
\hline
\end{tabular}

DDC, L-dopa decarboxylase; ETP, elective termination of pregnancy; IRS, immunoreactive score; RM, recurrent miscarriage; SM, spontaneous miscarriage.

showed very little DDC expression, resulting in low double staining in triple filter excitation in both samples (Fig. 6I and M).

In both ETP (Fig. 6N, O and P) and RM (Fig. 6Q, R and $\mathrm{S})$ samples, decidual stroma cells, stained in green (Fig. $6 \mathrm{O}$ and R), showed a coexpression for DDC (Fig. 6P and $\mathrm{S}$ ). Furthermore, prolactin-negative cells expressing DDC could be detected, suggesting a DDC-positive cell

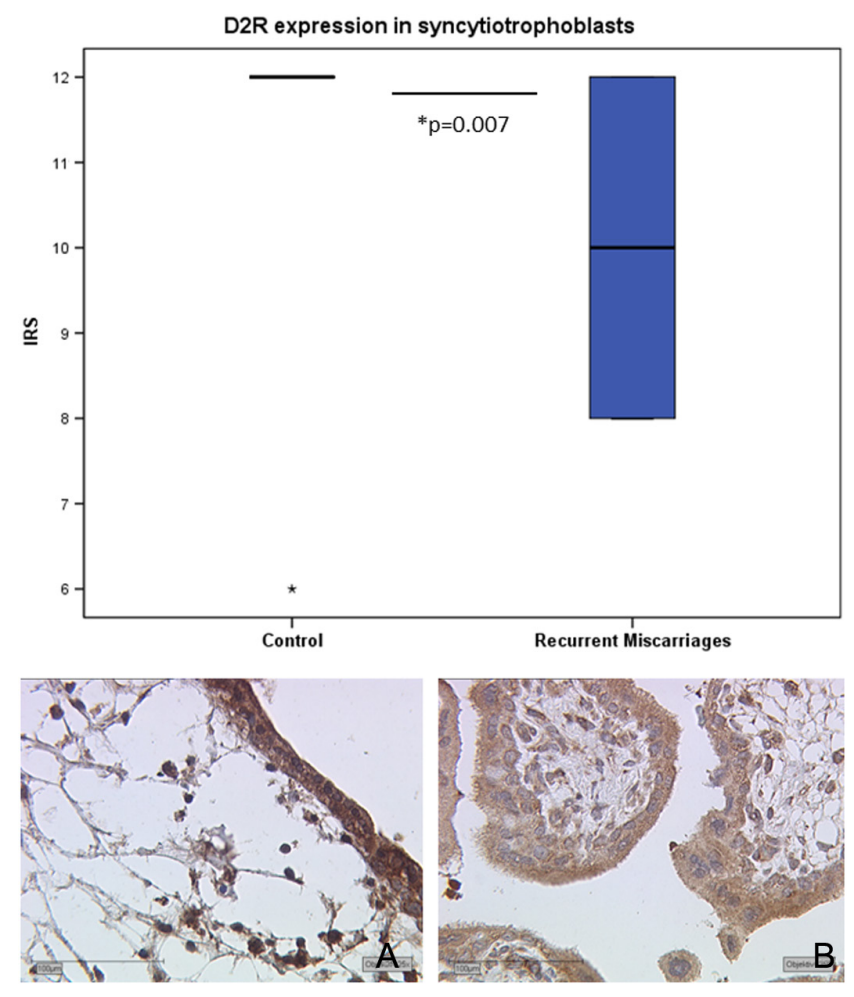

Figure 2

D2R protein expression in syncytio- and cytotrophoblasts. Boxplot of D2R expression in syncytiotrophoblasts of control placental tissue and recurrent miscarriages. In syncytiotrophoblasts of control placental tissue $(A, \times 25)$ a significantly higher expression and distribution of D2R expression could be detected in comparison to the recurrent miscarriages $(B, \times 25)$. D2R, $D_{2}$-dopamine receptor; IRS, immunoreactive score.

http://www.endocrineconnections.org https://doi.org/10.1530/EC-18-0126

(c) 2018 The authors Published by Bioscientifica Ltd
Table 4 Raw numbers to Fig. 2.

\begin{tabular}{|c|c|c|c|}
\hline & IRS mean & IRS 25th percentile & IRS 75th percentile \\
\hline \multicolumn{4}{|c|}{ D2R expression in syncytiotrophoblasts } \\
\hline ETP & 12 & 12 & 12 \\
\hline RM & 10 & 8 & 12 \\
\hline
\end{tabular}

$D 2 R, D_{2}$-dopamine receptor; ETP, elective termination of pregnancy; IRS, immunoreactive score; RM, recurrent miscarriage.

type beneath maternal decidual stromal cells and foetal EVT in the decidua.

\section{Discussion}

In this study, the regulation of DDC and D2R has been described in the placenta of healthy pregnancies and in SMs as well as RMs. The nature of our sample collection of legal termination of pregnancy cases of SMs and RMs does not allow large sample collections as for example shown in cancer studies. Therefore, studies of first trimester placental tissue are always of limited numbers. That is why type 2 errors may occur in general in these types of studies. A significant downregulation of DDC expression in trophoblasts and the decidua of RMs and a significantly reduced expression of D2R in syncytiotrophoblats and cytotrophoblasts of miscarriages in comparison to healthy pregnancies could be identified. As DDC is involved in the synthesis of dopamine, downregulation of DDC and $\mathrm{D} 2 \mathrm{R}$ in trophoblasts of RMs reflects a reduced signal cascade of catecholamines on the foetal side. Further studies are necessary to answer the question, whether a negative feedback loop of biologic active amines leads to a downregulation of DDC in miscarriages. A compensational reduced synthesis of amines induced by the DDC could also be discussed in this situation. Less production of amines may further lead to a decrease in epinephrine synthesis and consequently a reduced D2R expression. Blohberger et al. detected DDC expression in theca cells of the ovary and assume a correlation between DDC expression and higher dopamine levels within the ovary (6). Generation of dopamine from L-DOPA is the standard treatment for Parkinson's disease $(20,21,22)$. DDC activity regulation plays an important role during the treatment of Parkinson's disease, and fluctuation of DDC activity can cause severe side effects of chronic L-DOPA administration $(23,24)$.

The aims of this study included the analysis of the influence of endogene amines on DDC expression in

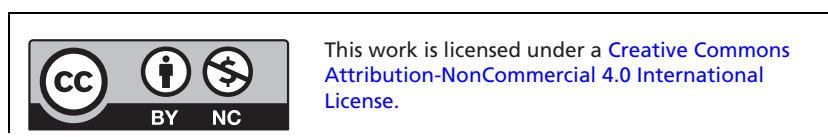



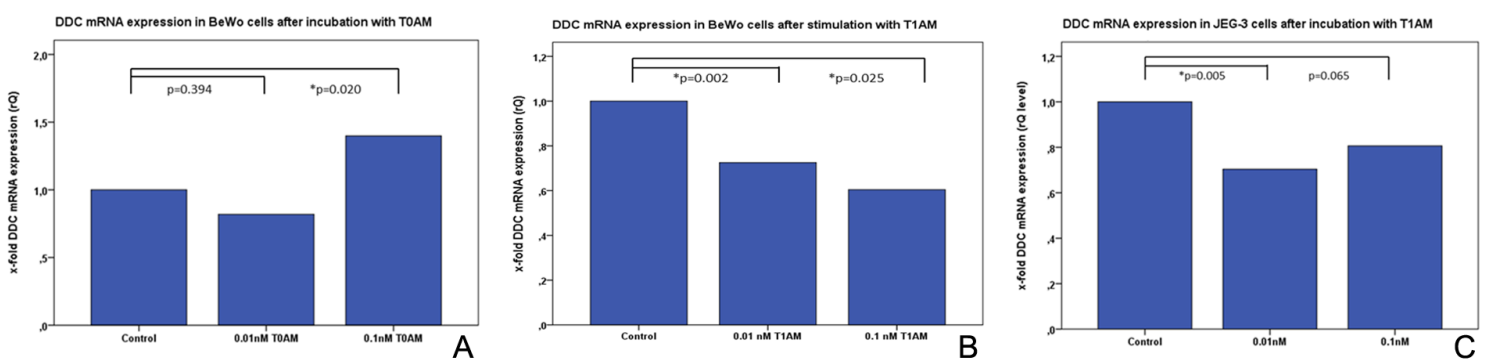

Figure 3

Real-time TaqMan PCR in BeWo and JEG-3 cells after stimulation with $T_{0} A M$ and $T_{1} A M$. (A) Bar chart of DDC mRNA expression in BeWo cells after incubation with $\mathrm{T}_{0} \mathrm{AM}$ detected via Real-time TaqMan-PCR. $0.1 \mathrm{nM} \mathrm{T}_{0} \mathrm{AM}$ induced a significant downregulation of DDC mRNA $(P=0.020)$. Downregulation of DDC mRNA after incubation with $0.01 \mathrm{nM} \mathrm{T_{0 } A M}$ was not significant $(P=0.394)$. b) Bar chart of DDC mRNA expression in BeWo cells after incubation with $\mathrm{T}_{1} \mathrm{AM}$ detected via Real-time TaqMan PCR. Both $0.001 \mathrm{nM}$ and $0.1 \mathrm{nM} \mathrm{T}_{1} \mathrm{AM}$ induced a significant downregulation of DDC mRNA expression. (C) Bar chart of DDC mRNA expression in JEG-3 cells after incubation with $T_{1} A M$ detected via Real-time TaqMan PCR. DDC mRNA expression was significantly

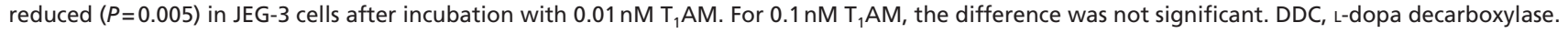

trophoblast model cells and to determine whether the ligands may be responsible for the induction of miscarriages. Enhanced transformation of thyroid hormones into biological active amines may partly be responsible for miscarriages. Miscarriages are accompanied by a downregulation of the classical THRs, which can be due to an alteration in the transformation of thyroid hormones into TAs (15). The latter are closely related to classical monoamines like dopamine, and they can function via TAAR1 (3). Harmeier et al. investigated TAAR1 and D2R heteromers in neuronal cells and pointed towards a crosstalk between TAAR1 and D2R (3). In our study, we were able to demonstrate that $\mathrm{T}_{3} / \mathrm{T}_{4}$ metabolites can downregulate DDC mRNA and protein expression in trophoblast model cells. Reduction of DDC expression induced by endogen amines, such as $\mathrm{T}_{0} \mathrm{AM}$ and $\mathrm{T}_{1} \mathrm{AM}$, is possibly caused by a product inhibition through the transformation of thyroid hormones into $\mathrm{T}_{0} \mathrm{AM}$ und $\mathrm{T}_{1} \mathrm{AM}$. A reduced level of thyroid hormones is described in disturbed pregnancies, which may consequently lead to a reduced expression of DDC and D2R in miscarriages. It also seems likely, that hypothyroidism or thyrotoxicosis leads to thyroid hormones dysregulation in placental tissue. Thus would also cause a dysregulation of thyroid hormone degradation products. These act not only on the DDC expression, but also on the heterodimer of D2R and TAAR1.

The influence of endogen amines on DDC has been analysed in BeWo- as well as JEG-3 trophoblast model cells, and in both cell lines, different DDC expression trends could be detected. BeWo cells are able to fuse, and they can form a syncytium and therefore rather resemble the characteristics of syncytiotrophoblasts (25). JEG-3 cells on the other hand resemble the characteristics of EVTs $(26,27)$. Due to the differing characteristics of BeWo and JEG-3 cells, different influences of the tested stimulants were detected on the expression patterns of DDC in both cell lines.

Vassiliou et al. also focused on DDC in the placenta, and they purified and identified Annexin $\mathrm{V}$ as an

Table 5 Raw numbers to Fig. 3.

\begin{tabular}{|c|c|c|}
\hline & $\mathbf{T}_{0} \mathbf{A M}$ & $\mathbf{T}_{\mathbf{1}} \mathbf{A M}$ \\
\hline \multicolumn{3}{|c|}{ DDC mRNA expression in BeWo cells after incubation with } \\
\hline Control & 1 & 1 \\
\hline $0.01 \mathrm{nM}$ & 0.85 & 0.70 \\
\hline \multirow[t]{2}{*}{$0.1 \mathrm{nM}$} & 1.45 & 0.60 \\
\hline & $\mathrm{T}_{1} \mathrm{AM}$ & \\
\hline \multicolumn{3}{|c|}{ DDC mRNA expression in JEG-3 cells after incubation with } \\
\hline Control & 1 & \\
\hline $0.01 \mathrm{nM}$ & 0.7 & \\
\hline $0.1 \mathrm{nM}$ & 0.8 & \\
\hline
\end{tabular}

DDC, L-dopa decarboxylase. 
DDC protein expression in BeWo cells after stimulation with TOAM
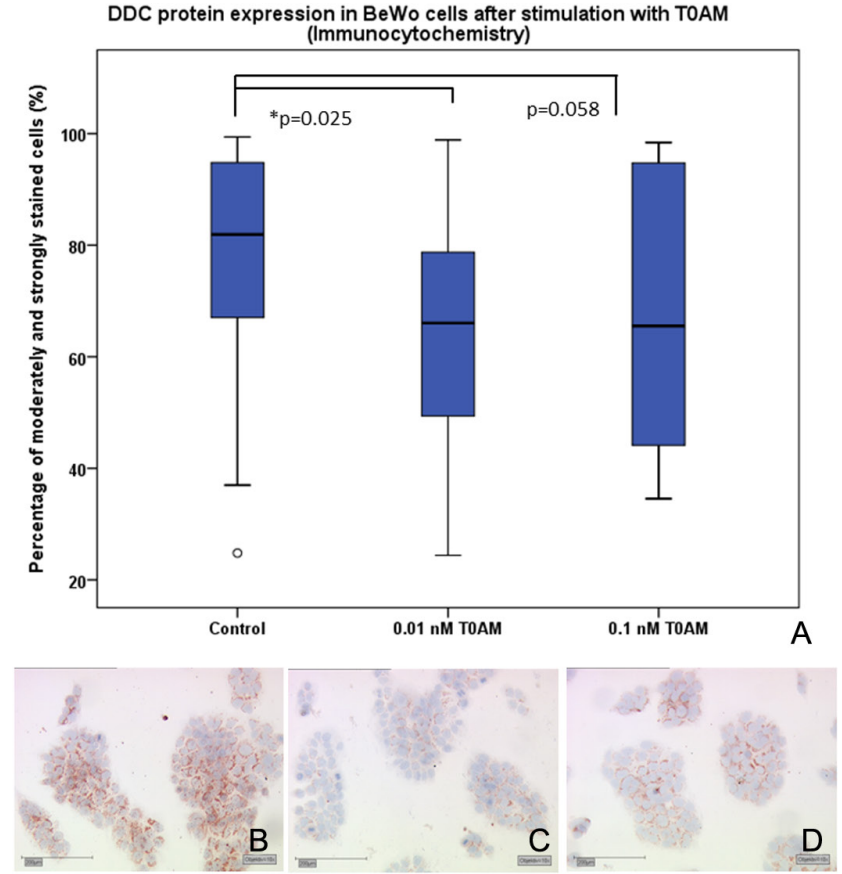

DDC protein expression in BeWo cells after stimulation with T1AM
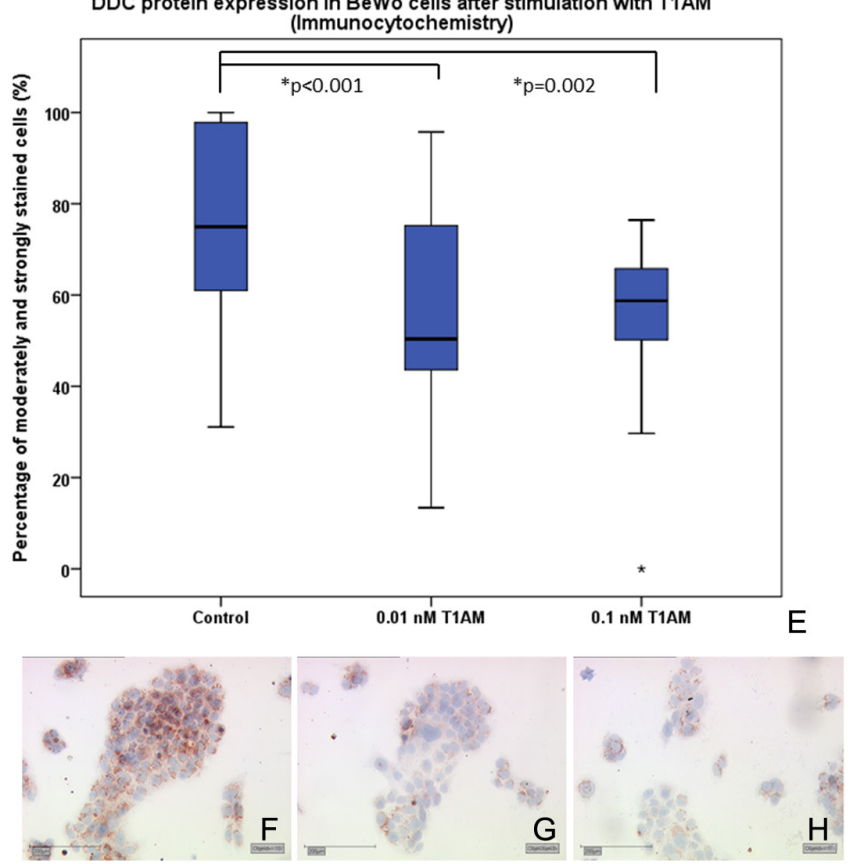

\section{Figure 4}

Immunocytochemistry of DDC protein expression in BeWo cells after stimulation with $\mathrm{T}_{0} \mathrm{AM}$ and $\mathrm{T}_{1} \mathrm{AM}$. (A) Boxplot analysis of DDC expression showing a significant downregulation of DDC expression induced by $0.01 \mathrm{nM} \mathrm{T} \mathrm{T}_{0} \mathrm{AM}(P=0.025)$. (B) DDC staining of control BeWo cells, (C) reduced DDC staining of BeWo cells treated with $0.01 \mathrm{nM} \mathrm{T} \mathrm{T}_{0} \mathrm{AM}$, (D) slightly reduced but not significant staining of BeWo cells treated with $0.1 \mathrm{nM} \mathrm{T}_{0} \mathrm{AM}$. (E) Boxplot analysis of DDC expression showing a significant downregulation of DDC expression induced by $0.01 \mathrm{nM}$ and $0.1 \mathrm{nM} \mathrm{T}_{1} \mathrm{AM}$. (F) DDC staining of control BeWo cells, (G) reduced DDC staining in BeWo cells after incubation with $0.01 \mathrm{nM}$ and $0.1 \mathrm{nM} \mathrm{T}_{1} \mathrm{AM}(\mathrm{G})$. DDC, L-dopa decarboxylase $(\mathrm{H})$.

endogenous inhibitor of DDC activity from the human placenta by mass spectrometry (5). The study group presumes that the existence of the endogen inhibitor of DDC may explain the lack of DDC activity in the decarboxylation of L-DOPA (5). In addition, very early studies showed that thyroid hormones can influence DDC in foetal tissue (28). Maternal hypothyroxinaemia can lead to impairment in the development of the foetal brain (28). The authors also found that this is accompanied by dysgenesis of certain neurotransmitter metabolic activities (choline acetyltransferase and DOPA decarboxylase) (28).

In conclusion, within this study, we could show an influence of thyroid hormone metabolites on the expression of DDC and D2R in healthy pregnancies and RMs. Therefore, thyroid hormone metabolites may influence the placental catecholamine receptor system. This study describes the status of DDC and D2R expression in decidual tissue. Since there is no activity assay for DDC in trophoblast cell lines, additional studies are needed to

Table 6 Raw numbers to Fig. 4.

\begin{tabular}{|c|c|c|c|}
\hline & Strongly stained cells mean (\%) & 25th percentile (\%) & 75th percentile (\%) \\
\hline \multicolumn{4}{|c|}{ DDC protein expression in BeWo cells after stimulation with $\mathrm{T}_{0} \mathrm{AM}$} \\
\hline Control & 82 & 68 & 92 \\
\hline $0.01 \mathrm{nM}$ & 65 & 50 & 77 \\
\hline $0.1 \mathrm{nM}$ & 65 & 45 & 92 \\
\hline \multicolumn{4}{|c|}{ DDC protein expression in BeWo cells after stimulation with $T_{1} A M$} \\
\hline Control & 75 & 61 & 98 \\
\hline $0.01 \mathrm{nM}$ & 50 & 43 & 75 \\
\hline $0.1 \mathrm{nM}$ & 60 & 50 & 66 \\
\hline
\end{tabular}

DDC, L-dopa decarboxylase.

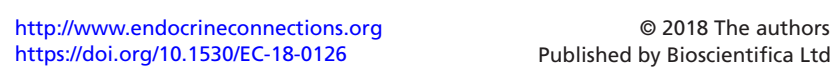



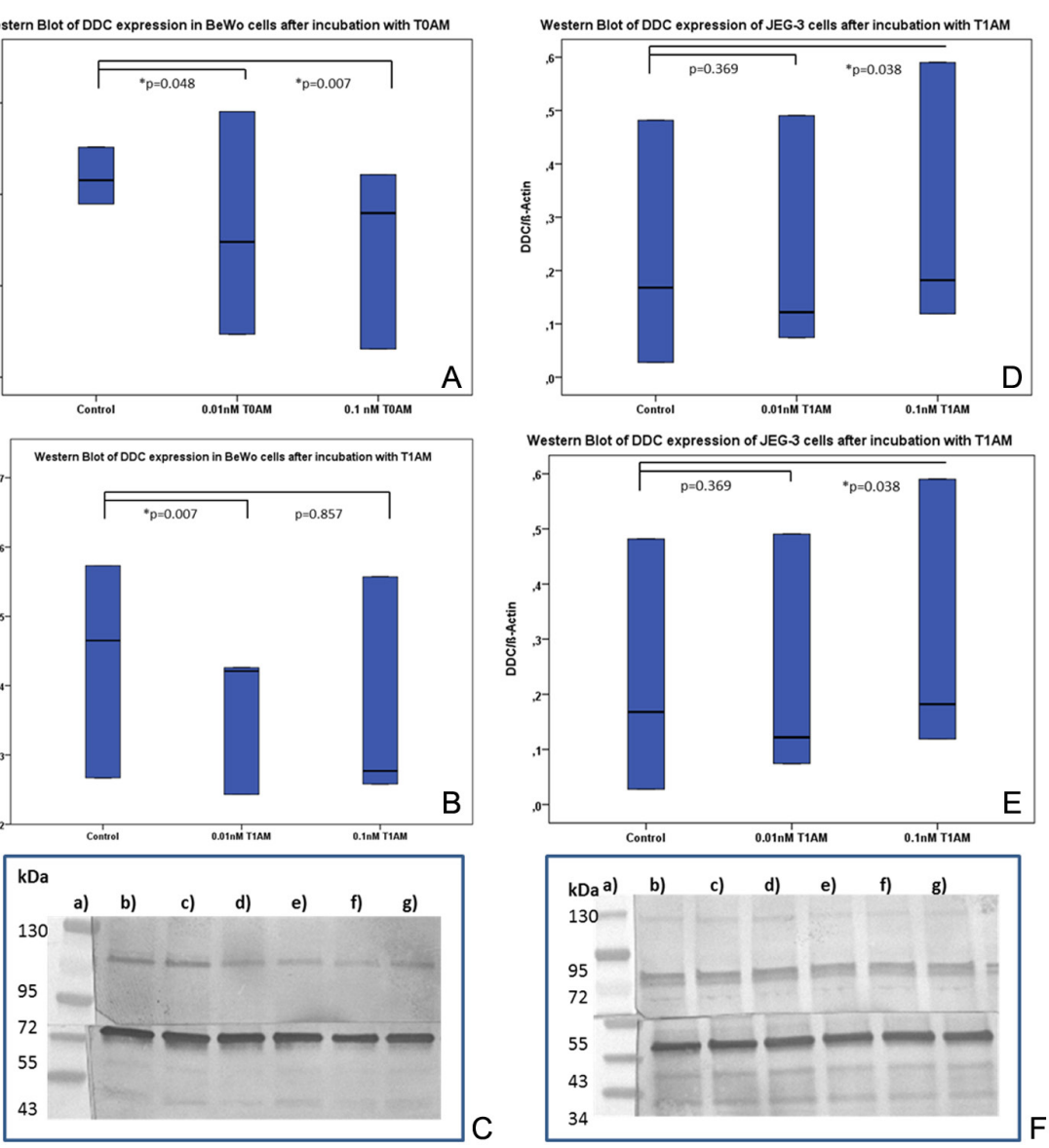

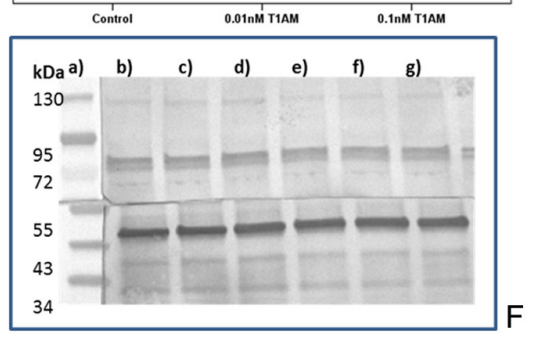

Figure 5

Western blot analysis of DDC protein expression in BeWo and JEG-3 cells after stimulation with $T_{0} A M$ and $T_{1} A M$. (A) Boxplot analysis of DDC expression in BeWo cells after incubation with $\mathrm{T}_{0} \mathrm{AM}$, (B) boxplot analysis of DDC expression in BeWo cells after incubation with $\mathrm{T}_{1} \mathrm{AM},(\mathrm{C})$ picture of Western blot membrane of BeWo cells where (a) standard protein ladder (Page Ruler Prestained Protein Ladder; Product\# 26616; Thermo Scientific). (b, e) BeWo cell control group. (c) BeWo cells stimulated with $0.01 \mathrm{nM} \mathrm{T_{0 }} A M$, (d) BeWo cells stimulated with $0.1 \mathrm{nM} \mathrm{T}_{0} \mathrm{AM}$. ( $\mathrm{f}$ ) BeWo cells stimulated with $0.01 \mathrm{nM} \mathrm{T}_{1} \mathrm{AM}$. (g) BeWo cells stimulated with $0.1 n M T_{1} A M$. (D, A) Boxplot analysis of DDC expression in JEG-3 cells after incubation with $\mathrm{T}_{0} \mathrm{AM},(\mathrm{E})$ boxplot analysis of DDC expression in JEG-3 cells after incubation with $T_{1} A M,(F)$ picture of Western blot membrane of JEG-3 cells where (a) Standard protein ladder (Page Ruler Prestained Protein Ladder; Product\# 26616; Thermo Scientific). (b, e) Jeg3 cell control group. (c) Jeg3 cells stimulated with $0.01 \mathrm{nM}$ $\mathrm{T}_{0} \mathrm{AM}$. (d) Jeg3 cells stimulated with $0.1 \mathrm{nM} \mathrm{T}_{0} \mathrm{AM}$. (f) Jeg 3 cells stimulated with $0.01 \mathrm{nM} \mathrm{T}_{1} \mathrm{AM}$. (g) Jeg3 cells stimulated with $0.1 \mathrm{nM} \mathrm{T}$ AM. DDC, L-dopa decarboxylase. investigate the functional correlations of DDC activity. Therefore, it can currently not be determined, whether our findings are of causative or associative nature. Future studies are necessary to analyse the effect of dopamine or epinephrine on DDC expression in the placenta and its influence on the pregnancy outcome. Furthermore, ligands that are able to upregulate DDC and D2R expression in trophoblasts should be identified.

Table 7 Raw numbers to Fig. 5.

\begin{tabular}{|c|c|c|c|}
\hline & DDC/ $\beta$-actin mean & DDC/ $\beta$-actin 25th percentile & DDC/ $\beta$-actin 75th percentile \\
\hline \multicolumn{4}{|c|}{ Western blot of DDC expression in BeWo cells after incubation with $\mathrm{T}_{0} \mathrm{AM}$} \\
\hline Control & 0.63 & 0.58 & 0.70 \\
\hline $0.01 \mathrm{nM}$ & 0.50 & 0.30 & 0.78 \\
\hline $0.1 \mathrm{nM}$ & 0.56 & 0.26 & 0.64 \\
\hline \multicolumn{4}{|c|}{ Western blot of DDC expression in BeWo cells after incubation with $T_{1} A M$} \\
\hline Control & 0.47 & 0.27 & 0.57 \\
\hline $0.01 \mathrm{nM}$ & 0.42 & 0.24 & 0.43 \\
\hline \multirow[t]{2}{*}{$0.1 \mathrm{nM}$} & 0.28 & 0.26 & 0.56 \\
\hline & DDC/ $\beta$-actin mean & 25th percentile & 75th percentile \\
\hline \multicolumn{4}{|c|}{ Western blot of DDC expression in JEG-3 cells after incubation with $\mathrm{T}_{0} \mathrm{AM}$} \\
\hline Control & 0.19 & 0.12 & 0.63 \\
\hline $0.01 \mathrm{nM}$ & 0.24 & 0.14 & 0.89 \\
\hline $0.1 \mathrm{nM}$ & 0.21 & 0.04 & 0.51 \\
\hline \multicolumn{4}{|c|}{ Western blot of DDC expression in JEG-3 cells after incubation with $T_{1} A M$} \\
\hline Control & 0.18 & 0.03 & 0.48 \\
\hline $0.01 \mathrm{nM}$ & 0.13 & 0.08 & 0.49 \\
\hline $0.1 \mathrm{nM}$ & 0.19 & 0.13 & 0.59 \\
\hline
\end{tabular}

DDC, L-dopa decarboxylase.

$\begin{array}{lr}\text { http://www.endocrineconnections.org } & \text { () } 2018 \text { The authors } \\ \text { https://doi.org/10.1530/EC-18-0126 } & \text { Published by Bioscientifica Ltd }\end{array}$



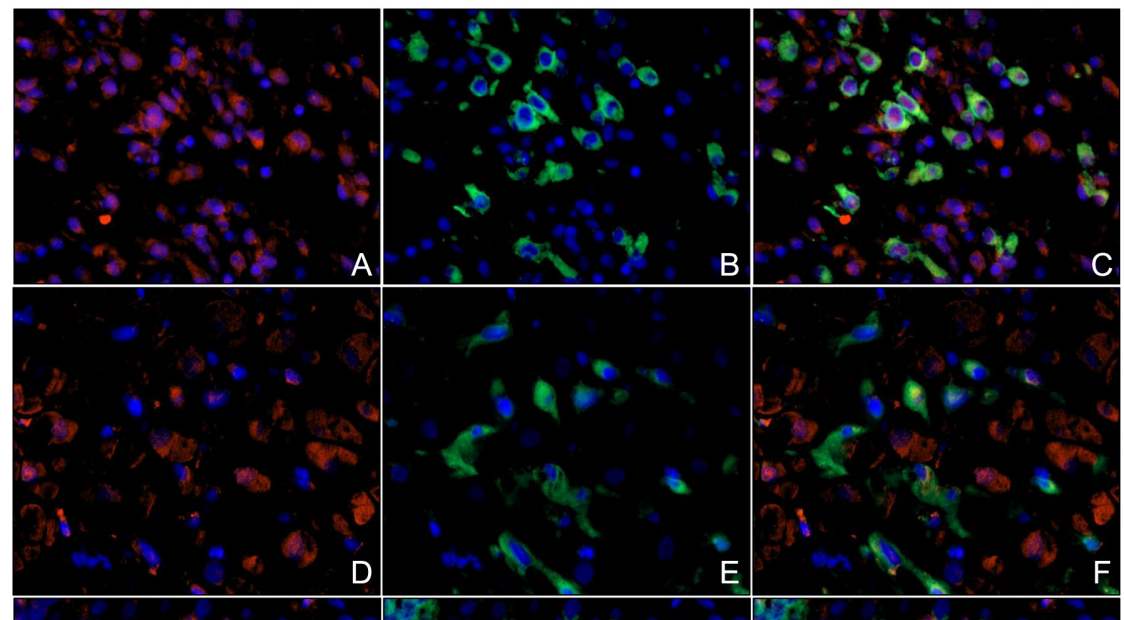

\section{Figure 6}

Double-immunofluorescence (A-F) with anti-D2R (red) and anti-HLAG (green) antibodies. (A) D2R expression in decidua of ETP placenta stained in red. (B) HLAG expression in decidua of ETP placenta stained in green. (C) Double staining of both D2R and HLAG. A double expression is visible in yellow. (D) D2R expression in decidua of RM placenta stained in red. (E) HLAG expression in decidua of RM placenta stained in green. (F) Double staining of both D2R and HLAG. A double expression is visible in yellow. (G-M) Doubleimmunofluorescence with anti-DDC (red) and anti-HLAG (green) antibodies. (G) DDC expression in decidua of ETP placenta stained in red. (H) HLAG expression in decidua of ETP placenta stained in green. (I) Double staining of both DDC and HLAG. A double expression is visible in yellow. (K) DDC expression in decidua of RM placenta stained in red. (L) HLAG expression in decidua of RM placenta stained in green. (M) Double staining of both DDC and HLAG. A double expression is visible in yellow. (N-S) Doubleimmunofluorescence with anti-DDC (red) and anti-prolactin (green) antibodies. (N) DDC expression in decidua of ETP placenta stained in red. (O) Prolactin expression in decidua of ETP placenta stained in green. $(P)$ Double staining of both DDC and prolactin. A double expression is visible in yellow. (Q) DDC expression in decidua of RM placenta stained in red. (R) Prolactin expression in decidua of RM placenta stained in green. (S) Double staining of both DDC and prolactin. A double expression is visible in yellow. DDC, L-dopa decarboxylase; D2R, $\mathrm{D}_{2}$-dopamine receptor; ETP, elective termination of pregnancy; $\mathrm{RM}$, recurrent miscarriage.

\section{Supplementary data}

This is linked to the online version of the paper at https://doi.org/10.1530/ EC-18-0126.

\section{Declaration of interest}

The authors declare that they have no conflict of interest that could be perceived as prejudicing the impartiality of the research reported.

\section{Funding}

The study was funded by the Bayerische Gleichstellungsförderung (BGF) 2016, Germany.

http://www.endocrineconnections.org https://doi.org/10.1530/EC-18-0126

(c) 2018 The authors Published by Bioscientifica Ltd
Author's contribution statement

A $V$ and $U \mathrm{~J}$ conceived and designed the experiments. M G, S S, C K and Si $\mathrm{H}$ performed the experiments. A V, U J, M G, S S, St $\mathrm{H}$ and $\mathrm{K} \mathrm{H}$ analysed the data. A V, U J, M G, S S and K H wrote the research article. All authors read and approved the manuscript. S M, K H, H H, C A, S H and D M did the final revision of the manuscript.

\section{Acknowledgements}

The authors thank Sandra Schulze for her excellent technical assistance.

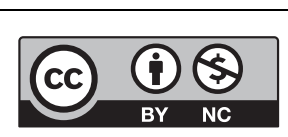

This work is licensed under a Creative Commons Attribution-NonCommercial 4.0 International License. 


\section{References}

1 Vaillancourt C, Petit A \& Belisle S. Expression of human placental D2-dopamine receptor during normal and abnormal pregnancies. Placenta 199819 73-80. (https://doi.org/10.1016/S01434004(98)90101-1)

2 Belisle S, Petit A, Gallot-Payet N, Lehoux J-G, bellabarba D, Escher E \& Guillon G. Endocrine control of hPL and hCG production by the human placenta. Trophoblast Research 19926 163-172. (https://doi. org/10.1016/S0143-4004(05)80313-3)

3 Harmeier A, Obermueller S, Meyer CA, Revel FG, Buchy D, Chaboz S, Dernick G, Wettstein JG, Iglesias A, Rolink A, et al. Trace amineassociated receptor 1 activation silences GSK3beta signaling of TAAR1 and D2R heteromers. European Neuropsychopharmacology 2015 25 2049-2061. (https://doi.org/10.1016/j.euroneuro.2015.08.011)

4 Strange PG. Antipsychotic drugs: importance of dopamine receptors for mechanisms of therapeutic actions and side effects. Pharmacological Reviews 200153 119-133.

5 Vassiliou AG, Fragoulis EG \& Vassilacopoulou D. Detection, purification and identification of an endogenous inhibitor of L-Dopa decarboxylase activity from human placenta. Neurochemical Research 200934 1089-1100. (https://doi.org/10.1007/s11064-008-9879-2)

6 Blohberger J, Buck T, Berg D, Berg U, Kunz L \& Mayerhofer A. L-DOPA in the human ovarian follicular fluid acts as an antioxidant factor on granulosa cells. Journal of Ovarian Research 2016962. (https://doi.org/10.1186/s13048-016-0269-0)

7 Papadopoulos EI, Fragoulis EG \& Scorilas A. Human L-DOPA decarboxylase mRNA is a target of miR-145: a prediction to validation workflow. Gene 2015554 174-180. (https://doi. org/10.1016/j.gene.2014.10.043)

8 Hoefig CS, Zucchi R \& Kohrle J. Thyronamines and derivatives: physiological relevance, pharmacological actions, and future research directions. Thyroid 201626 1656-1673. (https://doi.org/10.1089/ thy.2016.0178)

9 Ohara N, Tsujino T \& Maruo T. The role of thyroid hormone in trophoblast function, early pregnancy maintenance, and fetal neurodevelopment. Journal of Obstetrics and Gynaecology Canada 2004 26 982-990. (https://doi.org/10.1016/S1701-2163(16)30420-0)

10 Pestka A, Fitzgerald JS, Toth B, Markert UR \& Jeschke U. Nuclear hormone receptors and female reproduction. Current Molecular Medicine 201313 1066-1078. (https://doi.org/10.2174/1566524011313070002)

11 Evans IM, Sinha AK, Pickard MR, Edwards PR, Leonard AJ \& Ekins RP. Maternal hypothyroxinemia disrupts neurotransmitter metabolic enzymes in developing brain. Journal of Endocrinology $1999 \mathbf{1 6 1}$ 273-279. (https://doi.org/10.1677/joe.0.1610273)

12 Peleg D, Cada S, Peleg A \& Ben-Ami M. The relationship between maternal serum thyroid-stimulating immunoglobulin and fetal and neonatal thyrotoxicosis. Obstetrics and Gynecology 200299 1040-1043.

13 Barber KJ, Franklyn JA, McCabe CJ, Khanim FL, Bulmer JN, Whitley GS \& Kilby MD. The in vitro effects of triiodothyronine on epidermal growth factor-induced trophoblast function. Journal of Clinical Endocrinology and Metabolism 200590 1655-1661. (https:// doi.org/10.1210/jc.2004-0785)

14 Kilby MD, Verhaeg J, Gittoes N, Somerset DA, Clark PM \& Franklyn JA. Circulating thyroid hormone concentrations and placental thyroid hormone receptor expression in normal human pregnancy and pregnancy complicated by intrauterine growth restriction (IUGR). Journal of Clinical Endocrinology and Metabolism 199883 2964-2971. (https://doi.org/10.1210/jcem.83.8.5002)
15 Ziegelmuller B, Vattai A, Kost B, Kuhn C, Hofmann S, Bayer B, Toth B, Jeschke U \& Ditsch N. Expression of thyroid hormone receptors in villous trophoblasts and decidual tissue at protein and mRNA levels is downregulated in spontaneous and recurrent miscarriages. Journal of Histochemistry and Cytochemistry 201563 511-523. (https://doi.org/10.1369/0022155415582052)

16 Brix K, Fuhrer D \& Biebermann H. Molecules important for thyroid hormone synthesis and action - known facts and future perspectives. Thyroid Research 20114 (Supplement 1) S9. (https://doi. org/10.1186/1756-6614-4-S1-S9)

17 Stavrou S, Gratz M, Tremmel E, Kuhn C, Hofmann S, Heidegger H, Peryanova M, Hermelink K, Hutter S, Toth B, et al. TAAR1 induces a disturbed GSK3beta phosphorylation in recurrent miscarriages through the ODC. Endocrine Connections 20187 372-384. (https:// doi.org/10.1530/EC-17-0272)

18 Remmele W \& Stegner HE. Recommendation for uniform definition of an immunoreactive score (IRS) for immunohistochemical estrogen receptor detection (ER-ICA) in breast cancer tissue. Pathologe 19878 138-140.

19 Pestka A, Toth B, Kuhn C, Hofmann S, Wiest I, Wypior G, Friese K \& Jeschke U. Retinoid X receptor alpha and retinoids are key regulators in apoptosis of trophoblasts of patients with recurrent miscarriages. Journal of Molecular Endocrinology 201147 145-156. (https://doi. org/10.1530/JME-11-0002)

20 Connolly BS \& Lang AE. Pharmacological treatment of Parkinson disease: a review. JAMA 2014311 1670-1683. (https://doi. org/10.1001/jama.2014.3654)

21 Lloyd KG, Davidson L \& Hornykiewicz O. The neurochemistry of Parkinson's disease: effect of L-dopa therapy. Journal of Pharmacology and Experimental Therapeutics 1975195 453-464.

22 Olanow CW. Levodopa: effect on cell death and the natural history of Parkinson's disease. Movement Disorders 201530 37-44. (https:// doi.org/10.1002/mds.26119)

23 Berry MD, Juorio AV, Li XM \& Boulton AA. Aromatic L-amino acid decarboxylase: a neglected and misunderstood enzyme. Neurochemical Research 199621 1075-1087. (https://doi.org/10.1007/ BF02532418)

24 Liu J, Zheng D, Zhou DY, Li QJ, Xaio SH, Yan J, Li Y \& Xing YG. Cloning and sequencing of human neuronal aromatic L-amino acid decarboxylase gene and its therapeutic effects on Parkinson's disease. Chinese Journal of Clinical Rehabilitation 2004 8 3893-3895.

25 Hutter S, Morales-Prieto DM, Andergassen U, Tschakert L, Kuhn C, Hofmann S, Markert UR \& Jeschke U. Gal-1 silenced trophoblast tumor cells (BeWo) show decreased syncytium formation and different miRNA production compared to non-target silenced BeWo cells. Cell Adhesion and Migration 201610 28-38. (https://doi.org/10.1 080/19336918.2015.1089377)

26 Jeschke U, Stahn R, Goletz C, Wang X, Briese V \& Friese K. hCG in trophoblast tumour cells of the cell line Jeg3 and hCG isolated from amniotic fluid and serum of pregnant women carry oligosaccharides of the sialyl Lewis X and sialyl Lewis a type. Anticancer Research 2003 23 1087-1092.

27 Mary Photini S, Chaiwangyen W, Weber M, Al-Kawlani B, Favaro RR, Jeschke U, Schleussner E, Morales-Prieto DM \& Markert UR. PIM kinases 1, 2 and 3 in intracellular LIF signalling, proliferation and apoptosis in trophoblastic cells. Experimental Cell Research 2017359 275-283. (https://doi.org/10.1016/j.yexcr.2017.07.019)

28 Ekins RP, Sinha AK, Pickard MR, Evans IM \& al Yatama F. Transport of thyroid hormones to target tissues. Acta Medica Austriaca 199421 26-34.

Received in final form 31 March 2018

Accepted 23 April 2018

Accepted Preprint published online 23 April 2018

\section{http://www.endocrineconnections.org}

https://doi.org/10.1530/EC-18-0126 (c) 2018 The authors Published by Bioscientifica Ltd

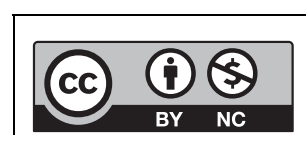

This work is licensed under a Creative Commons Attribution-NonCommercial 4.0 International License. 